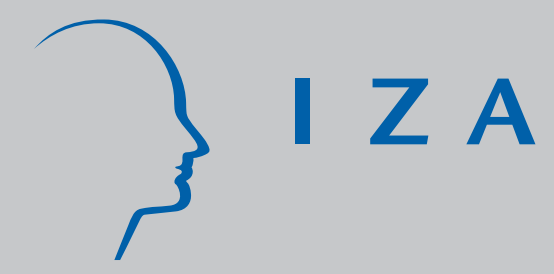

IZADP No. 3808

Internal Finance and Growth:

Microeconometric Evidence on Chinese Firms

Alessandra Guariglia

Xiaoxuan Liu

Lina Song

October 2008 


\title{
Internal Finance and Growth: Microeconometric Evidence on Chinese Firms
}

\author{
Alessandra Guariglia \\ University of Nottingham \\ Xiaoxuan Liu \\ Chinese Academy of Social Sciences \\ Lina Song \\ University of Nottingham \\ and IZA
}

Discussion Paper No. 3808

October 2008

\author{
IZA \\ P.O. Box 7240 \\ 53072 Bonn \\ Germany \\ Phone: +49-228-3894-0 \\ Fax: +49-228-3894-180 \\ E-mail: iza@iza.org
}

\begin{abstract}
Any opinions expressed here are those of the author(s) and not those of IZA. Research published in this series may include views on policy, but the institute itself takes no institutional policy positions.

The Institute for the Study of Labor (IZA) in Bonn is a local and virtual international research center and a place of communication between science, politics and business. IZA is an independent nonprofit organization supported by Deutsche Post World Net. The center is associated with the University of Bonn and offers a stimulating research environment through its international network, workshops and conferences, data service, project support, research visits and doctoral program. IZA engages in (i) original and internationally competitive research in all fields of labor economics, (ii) development of policy concepts, and (iii) dissemination of research results and concepts to the interested public.
\end{abstract}

IZA Discussion Papers often represent preliminary work and are circulated to encourage discussion. Citation of such a paper should account for its provisional character. A revised version may be available directly from the author. 


\section{ABSTRACT \\ Internal Finance and Growth: Microeconometric Evidence on Chinese Firms ${ }^{*}$}

Does the availability of internal finance constrain firm growth? Or does it foster it? To answer these questions, we use a panel of 407,096 Chinese firms over the period 2000-2005. We estimate dynamic assets growth equations augmented with cash flow, and find that the growth of state owned enterprises is not affected by cash flow, while that of privately owned firms is most affected. Considering that they represent $62 \%$ of the observations in our sample and that, in spite of being typically discriminated against by financial institutions, private firms have experienced sensational growth rates, our results suggest that internal finance has fostered rather than constrained their growth.

JEL Classification: D92

Keywords: $\quad$ assets growth, cash flow, financial constraints

Corresponding author:

Alessandra Guariglia

School of Economics

University of Nottingham

University Park

Nottingham, NG7 2RD

United Kingdom

E-mail: alessandra.guariglia@nottingham.ac.uk

\footnotetext{
${ }^{*}$ We thank E. Cannon, S. Fazzari, B. Fleischer, M. Marchica, P. Mizen, R. Mura, Y. Yao, and the participants to seminars at the Universities of Bath, Bristol, Durham, Manchester, and Newcastle, and to the 2007 workshop on the use of panel data in macroeconomics and finance organized by the Money, Macro and Finance Research Group, the $19^{\text {th }}$ UK Chinese Economic Association Annual Conference, and the Microeconomic Drivers of Growth in China Conference, for helpful comments. A. Guariglia and L. Song gratefully acknowledge financial support from the University of Nottingham Research on and in Asia Fund ASIA4246, and from the Leverhulme Trust under Programme Grant F/00 114/AM.
} 


\section{Introduction}

Over the period 2000-2005, Chinese firms achieved very high growth rates and generated large cash flow streams: their average assets growth was $8.0 \%$ and their average cash flow to capital ratio, $40.4 \%{ }^{1}$. Are these two features related? And if so, what is the nature of the link that connects them? Our paper seeks to answer these questions.

We provide a meaningful contribution to the literature on finance and economic growth. Numerous papers in this literature have used macro data to investigate the links between broad measures of financial development and growth, and generally found a positive relationship (see Levine, 2005, for a survey). Yet, China is a counterexample to these findings: in spite of a malfunctioning financial system, it has one of the fastest growing economies (Allen at al., 2005). The present paper helps to rationalize this puzzle (which we denote hereafter as the Chinese growth puzzle) by investigating the role played by the availability of internally generated funds in determining firm-level growth ${ }^{2}$.

Our research also relates to the literature on financing constraints. In recent years, a number of papers have analyzed the extent to which measures of internal finance (such as cash flow) affect firm investment in fixed capital, inventories, or $\mathrm{R} \& \mathrm{D}$, which can be seen as specific components of firm growth. Most of these studies interpret a positive link between cash flow and investment as an indicator of financial constraints $^{3}$. A financially constrained firm, for which it is difficult or too expensive to obtain external finance, will in fact only invest if it has sufficient internal funds, and will be forced to reduce its investment, and hence its growth, following drops in its cash flow. Yet, these financial constraints could transform themselves into financial stimuli for cash flow-rich firms with good investment prospects.

\footnotetext{
${ }^{1}$ These figures are obtained from our dataset, which is a large-scale enterprise survey conducted by the Chinese National Bureau of Statistics (NBS) over the period 2000-2005, and covering all state owned enterprises and other types of enterprises with annual sales of five million yuan (about $\$ 650,000$ ) or more. This dataset is thoroughly described in Section 3.

${ }^{2}$ To the best of our knowledge, this approach, which was pioneered in 2002 by Carpenter and Petersen who applied it to small US listed firms, has never been used with reference to a developing country. See Hutchinson and Xavier (2006) for an application to Belgium and Slovenia. Hereafter, we will use the terms internal finance, internally generated funds, and cash flow, interchangeably.

${ }^{3}$ This view (the financing constraints hypothesis) has, however, been challenged by Kaplan and Zingales (1997), Cleary (1999), and Cummins et al. (2006). See Schiantarelli (1995), Hubbard (1998), and Bond and Van Reenen (2007), for surveys of the literature on financing constraints and firm behavior.
} 
Given the heterogeneity that characterizes it, the Chinese economy represents an ideal laboratory for testing the financing constraints hypothesis. It contains in fact several types of firms, likely to face very different degrees of credit constraints. The two extreme groups are the state owned and the private enterprises. Because of their multi-functionality, i.e. their need to respond to both political and social stresses, as well as to economic objectives (Bai et al., 2006), the state owned enterprises (SOEs) typically experience soft budget constraints, and are able to obtain large amounts of loans from the banking system, despite their low profitability. These firms are therefore unlikely to face any financial constraints, and we do not expect their growth to be significantly affected by their internally generated funds. Private firms, on the other hand, make up the largest group, and constitute the engine of growth of the Chinese economy, with growth rates in excess of $10 \%$. Yet, these firms are typically discriminated against in terms of access to external funding (Allen et al., 2005) ${ }^{4}$. For these financially constrained firms, the ability to generate high cash flow streams may have played a significant role in fostering their spectacular growth rates.

Despite China being a very interesting case study, only a handful of papers attempted to test whether the financing constraints hypothesis holds for Chinese firms (Chow and Fung, 1998, 2000; Héricourt and Poncet, 2007). These studies are based on datasets made up of relatively small numbers of firms, only operating in major Chinese cities. We contribute to this literature in two important ways. First, we use a very large and relatively unexplored dataset, conducted by the Chinese NBS over the period 2000-2005, and made up of 407,096 unlisted manufacturing and mining firms, which sum up to $1,057,999$ observations. This dataset includes a large proportion of small and young firms, which are particularly likely to suffer from liquidity constraints. It provides us with a unique opportunity to carry out much sharper tests of the financing constraints hypothesis than those typically performed in the literature, which are mostly based on samples of relatively healthy listed US or UK firms ${ }^{5}$. To

\footnotetext{
${ }^{4}$ Until 1998, state owned commercial banks were instructed to lend only to state owned enterprises. The system was liberalized at the end of 1990s, when the Chinese Constitution acknowledged the private sector to be an integral part of the economy, and theoretically it is not in place any more. However, in practice, banks still consider private enterprises to be riskier than their public peers due to their short credit history and lower chance of being bailed out by the government. Evidence for this is given in World Bank (2003), which documents that over the period 1997-2000, only 12\% of the working capital of Chinese small and medium-sized enterprises (which are mainly private) came from bank loans.

${ }^{5}$ Most of the studies based on US data make use of Compustat, while studies based on the UK make use of Datastream. Only a few papers in the literature have tested the financing constraints hypothesis
} 
the best of our knowledge, the financing constraints hypothesis has never been tested using such a comprehensive dataset. Second, unlike Chow and Fung $(1998,2000)$ and Héricourt and Poncet (2007), who concentrate on firms' investment, we focus on the growth of firms' total assets, which encompasses all possible uses of cash flow. Hence, for financially constrained firms, we predict a relationship between internal finance and growth of the order of one-for-one.

We find that the growth of SOEs is not affected by the availability of cash flow, while that of foreign firms is moderately affected, and that of collective and private firms is most affected. These results are robust to accounting for investment opportunities in several ways, to considering assets growth net of cash, to defining our ownership categories in different ways, and to estimating an extended growth model. They suggest that SOEs are not subject to financing constraints, probably because of their multi-functionality, which guarantees them unlimited loans from the state banks. In contrast, foreign owned firms are financially constrained, although to a moderate degree, as they are also able to obtain funding from their parent company (Desai et al., 2004). Private and collective firms are the most financially constrained, being typically discriminated against by the banking sector.

Considering that private firms make up on average about $62 \%$ of the observations in our sample, the Chinese miracle, which was driven by these firms, may have been made possible by their ability to generate vast amounts of internal funds, which enabled them to grow, in spite of their inability to obtain external finance. For these firms, growth may therefore have been fostered rather than constrained by the availability of internal finance. Yet, if the competitive advantage of these firms were to be eroded ${ }^{6}$, lowering their ability to generate internal funds, their financing constraints could become binding. This could cause a significant reduction in economic growth. Thus, to make sure that the Chinese economy continues to thrive, measures will have to be taken ensuring a more widespread access to institutional finance.

The structure of the paper is as follows. Section 2 reviews the literature on the links between finance and growth in China, both from a macro and a micro perspective. Section 3 describes our dataset and presents some descriptive statistics.

using panels containing unlisted firms (see for instance Benito, 2005, and Guariglia, 2008), but their datasets are generally much smaller than ours.

${ }^{6}$ This could happen, for instance, as a consequence of rising labor costs, or more in general, as a consequence of increasing competition. 
Section 4 illustrates our baseline specification and estimation methodology. Section 5 describes our econometric results, and Section 6 concludes.

\section{Links between finance and growth in China}

\subsection{A macro perspective}

A number of studies have used provincial level panel data, over different time periods ranging between 1985 and 2003, to analyze the relationship between finance and growth in China, in an attempt to understand the Chinese growth puzzle. Among these, Liu and Li (2001) argue that the growth of national bank loans and self-raised funds are both positively related to the growth of provincial output. Similarly, Cheng and Degryse (2006) show that banking development spurs growth in China. Yet, Chen (2006) finds that Chinese growth has been fostered by the substitution of loans for state budget appropriation, but not by loan expansion itself, while Aziz and Duenwald (2002) find no evidence that bank lending boosts growth in Chinese provinces. Boyreau-Debray (2003) shows that credit extended by the banking sector has a negative impact on growth, which she attributes to the burden of supporting the state owned corporate sector. Finally, Guariglia and Poncet (2008) find that traditionally used indicators of financial development and China-specific indicators measuring the level of state interventionism in finance are generally negatively associated with growth. These effects have been gradually declining over time, and are weaker for high FDI recipients, suggesting that recent banking reforms have been successful, and that FDI may be used to alleviate the costs associated with the inefficient banking sector. These studies make use of different financial indicators, and different econometric techniques, and focus on different time periods, which might explain their mixed results. Yet, provincial data do not permit a full understanding of the relationship between finance and growth in China, as they ignore the considerable heterogeneity characterizing individual Chinese firms. Studies based on micro data are therefore necessary for this purpose.

\subsection{A micro perspective}

Other studies have adopted a micro perspective and use firm-level data to understand the links between finance and growth in China. Among these, a group of papers have looked at the links between specific sources of external finance and firm growth; 
another at the links between cash flow and investment in fixed capital (which is a significant component of firm growth).

Within the first group, Ayyagari et al. (2008) and Cull et al. (2007) focus on firm-level data to explain the high growth rates experienced in China, in spite of a poorly developed financial system. The former rely on the World Bank Investment Climate Survey dataset, which covers 2400 Chinese firms across 18 different cities, over the period 2000-2003. The authors analyze firm financing patterns, and show that a relatively small percentage of firms in their sample use formal bank finance, while reliance on informal finance is much stronger. They then question whether it is non-standard financing mechanisms that promote growth in China, but are unable to find conclusive evidence in favor of this hypothesis. Cull et al. (2007), on the other hand, use data drawn from the annual accounting reports filed by industrial firms with the NBS to investigate whether trade credit could have been what financed China's spectacular growth, in spite of its malfunctioning financial system. They conclude that trade credit did not play a significant role in explaining China's growth ${ }^{7}$. Neither of these studies provides therefore a solution to the Chinese growth puzzle.

Among the second group of papers, Chow and Fung (1998) study the relationship between investment and cash flow using a panel of 5825 manufacturing firms operating in Shanghai over the period 1989-1992, with the objective of testing the financing constraints hypothesis. They find that firms' investment is constrained by cash flow, and that the sensitivity of investment to cash flow is highest for private firms and lowest for foreign owned firms. State owned and collective firms also exhibit positive sensitivities, higher for the former. Chow and Fung (2000) exploit the same data set as Chow and Fung (1998) and, focusing once again on investment equations, show that small firms exhibit lower sensitivities of investment to cash flow than large firms. They explain this finding considering that small firms are dominated by non-state, fast growing enterprises, which may be using their working capital to smooth their fixed investment. These studies suggest that as cash flow plays an important role in determining firm investment, it is also likely to affect firm growth ${ }^{8}$.

\footnotetext{
${ }^{7}$ Allen et al. (2008a) reach a similar conclusion in a recent study of the financial system capacities of China and India.

${ }^{8}$ Also see Héricourt and Poncet (2007) who, using World Bank Investment Climate Survey data, show that, contrary to state owned firms, private firms' investment is strongly affected by their coverage ratio and debt to assets ratio.
} 
We provide a synthesis between these two groups of studies. Our paper connects with Ayyagari et al. (2008) and Cull et al. (2007), in the sense that it also uses firmlevel data to analyze firm growth. Yet, instead of focusing on the actual links between growth and specific sources of external finance, it follows the approach of the investment literature by assessing the extent to which firm growth is affected by the availability of internal finance (proxied by cash flow). As in the investment literature, a strong dependence of assets growth on cash flow can be seen as an indicator of financing constraints. If, following a decline in its internal funds, a firm is forced to reduce its growth (by reducing, for instance, its investment in fixed capital and/or working capital), one can infer that the firm finds it difficult to access external finance.

Yet, these financial constraints could be accompanied by increasing growth rates for firms with good investment prospects, able to generate large amounts of internal funds. This could have been the case for Chinese private firms and could explain why, in spite of a malfunctioning financial system, China has one of the fastest growing economies, and can be seen as a counterexample to the findings of the finance-growth literature (Allen et al., 2005). The Chinese miracle could in fact have been driven by highly profitable private firms, which were able to finance high growth levels only through their retained earnings. Thus, internal finance may have fostered rather than constrained their growth. In the remaining part of the paper, we formally test whether this has been the case.

\section{Data and summary statistics}

\subsection{Data}

We use data drawn from the annual accounting reports filed by industrial firms with the NBS over the period 2000-2005. All state-owned enterprises and other types of enterprises with annual sales of five million yuan (about $\$ 650,000$ ) or more are covered. These firms operate in the manufacturing and mining sectors and come from 31 provinces or province-equivalent municipal cities ${ }^{9}$. We dropped observations with negative sales; as well as observations with negative total assets minus total fixed

\footnotetext{
${ }^{9}$ China is administratively decomposed into 31 provincial units, which fall into three categories: 22 provinces or sheng; 4 autonomous regions or zizhiqu (Nei Monggol, Xinjiang, Tibet, Ningxia and Guangxi); and 4 municipal cities or zhixiashi, under direct supervision of the central power (Shanghai, Tianjin, Beijing, and, since 1997, Chongqing).
} 
assets; total assets minus liquid assets; and accumulated depreciation minus current depreciation. Firms that did not have complete records on our main regression variables were also dropped. Finally, to control for the potential influence of outliers, we excluded observations in the one percent tails of each of the regression variables. Our final dataset covers 407,096 mainly unlisted firms, which corresponds to $1,057,999$ firm-year observations ${ }^{10}$. Our panel is unbalanced, with number of observations ranging from a minimum of 130,306 in 2000 to a maximum of 233,727 in $2004^{11}$.

The NBS data contains a continuous measure of ownership, which is based on the fraction of paid-in-capital contributed by six different types of investors, namely the state; foreign investors (excluding those from Hong Kong, Macao, and Taiwan); investors from Hong Kong, Macao, and Taiwan; legal entities; individuals; and collective investors. The rationale for dividing foreign investors into those from Hong Kong, Macao, and Taiwan, and those from other parts of the world is that the former capture the so-called "round-tripping" foreign direct investment, whereby domestic firms may register as foreign invested firms from nearby regions to take advantage of the benefits (such as tax and legal benefits) granted to foreign invested firms (Huang, 2003). Ownership by legal persons is a mixture of ownership by state legal persons and private legal persons ${ }^{12}$, which represents a form of corporate ownership. Finally, collective firms are typically owned collectively by communities in urban or rural areas (the latter are known as Township and Village Enterprises or TVEs).

We grouped all foreign owned firms (from Hong-Kong, Macao, Taiwan, and other parts of the world) into a single category (which we labelled foreign); and all firms owned by legal entities, and individuals into a single category (labelled private $^{13}$. Following Cull et al. (2007), we then classified our firms into state owned,

\footnotetext{
${ }^{10}$ The Chinese NBS dataset does not allow separate identification of publicly listed companies in China. Specifically, it is difficult to track these companies as their legal identification numbers were changed as they went public (Liu and Xiao, 2004). Over the period considered, there were slightly more than 1000 listed companies operating in the manufacturing and mining sectors. This amounts to less than $0.3 \%$ of the total number of firms in our sample.

${ }^{11}$ See the Appendix for details about the structure of our panel and complete definitions of all variables used.

${ }^{12}$ Legal persons represent a mix of various domestic institutions, such as industrial enterprises, construction and real estate development companies, transportation and power companies, securities companies, trust and investment companies, foundations and funds, banks, technology and research institutions etc.

${ }^{13}$ Within this category, firms owned by individuals represent $69 \%$ of the total. As firms owned by legal persons include firms owned by state legal persons, one could question their inclusion in the private category. One reason for including them is that while the state's primary interest is mainly political (i.e.
} 
foreign, private, and collective, based on the shares of paid-in-capital contributed by our four types of investors over the period 2000-2005. Specifically, we classified firms according to their largest ownership share. For instance, if in a given year, the share of a firm's capital owned by foreign investors is $40 \%$, while the state and private investors each own (on average) 30\% of the firm's capital, then the firm is classified as foreign ${ }^{14}$.

Table 1 presents the distribution of our observations by ownership type and year. We can see that the composition of our sample underwent considerable changes over the period 2000-2005. In particular, the share of the sample comprised by SOEs has declined from $21.37 \%$ in 2000 to just $4.34 \%$ in 2005 , while the share comprised by private investors has increased from $41.48 \%$ to $73.53 \%$ over the same period, as a consequence of an ongoing process of privatization ${ }^{15}$. The share of collectively owned firms also suffered a significant decline, from $24.10 \%$ to $6.33 \%$. Collective enterprises have been extremely successful in the 1980s, and were typically granted tax advantages and easy bank loans (Byrd and Lin, 1990). Yet, in the 1990s, due to the increased competition by private firms and to the banking reforms, whereby banks started to scrutinize loan applications more carefully, these enterprises experienced declining profitability, and a slowdown in their growth. Reforming their ownership structure became a priority to reverse these trends (Song, 1990; Ho et al., 2003). Abraham et al. (2007) document that these firms can nowadays be considered as fully private. Given their different past, we, however, leave them as a separate category. Finally, the share comprised by foreign investors rose only moderately (from $12.22 \%$ to $15.38 \%$ ) between 2000 and 2005.

As our objective in this paper is not the study of the effects of firms' transitions from state owned to private or foreign on the degree of financing constraints that they face, in our subsequent analysis, we make use of time-invariant

aimed at maintaining employment levels or control over certain strategic industries), legal persons are profit-oriented (Wei et al., 2005). Since our dataset does not allow us to discriminate between state and non-state legal persons, we were unable to exclude the former from our private category. All our results were, however, robust to excluding all firms owned by legal persons from the private category.

${ }^{14}$ We derived ownership categories on the basis of the fraction of capital paid in by the various groups, rather than using registration codes. Registration codes are in fact not entirely reliable, as they are updated only with considerable delay (Dollar and Wei, 2007). Moreover, firms might have an incentive to falsely register as foreign simply to take advantage of the tax benefits accorded to the latter. All our results were robust to using registration-based ownership categories.

${ }^{15}$ In the first part of its transition, China was dominated by SOEs. After 1993, due both to the restructuring of ownership of SOEs and to the entry of new private firms in the market, the share of SOEs in the economy gradually declined, while that of private companies kept rising (Jefferson and Jian, 2006). 
measures of ownership. Hence, we classify firms into our four ownership categories, based on their largest average ownership shares calculated over the period 2000$2005^{16}$.

\subsection{Summary statistics}

In our empirical analysis, we focus on firm-level, growth defined as the growth of firms' total assets. Total assets include tangible fixed assets; intangible fixed assets; other fixed assets; accounts receivable; inventories; and other current assets (the main component of which is cash and equivalents). Table 2 shows the composition of total assets by ownership types. The share of the total assets of SOEs made up by tangibles (42.44\%) is much higher than the corresponding average share for the other three ownership groups (34.51\%). This can be explained by the overinvestment behavior that typically characterizes Chinese SOEs (Qin and Song, 2008). SOEs also have lower shares of accounts receivable and inventories: $12.60 \%$ and $17.14 \%$, compared to averages of $19.28 \%$ and $19.64 \%$ for the other groups. This suggests that, compared to other ownership types, SOEs are fairly different in terms of assets composition.

Table 3 presents sample means for a number of variables for our four ownership types. Once again, we see that SOEs are notably different from the other groups. Specifically, they exhibit very low growth rates: their mean assets growth is $0.60 \%$, compared to an average of $9.08 \%$ for the other three groups; their average sales growth is $0.84 \%$, compared to an average of $11.40 \%$ for the rest of the sample; and their average employment growth rate is negative $(-8.09 \%$, compared to $2.56 \%$ for the other groups). These low growth rates may reflect the fact that SOEs respond to social and political needs, as well as to economic objectives (Bai et al., 2006). SOEs are typically larger (in terms of assets and number of employees) and older than other groups: they employ an average of 347.42 employees, compared to 200.82 for the rest of the sample; their total assets are worth 390.50 (thousands of yuan) compared to 203.67 for the other three groups; and their average age is 24.71, compared to 7.82 for the rest of the sample. SOEs also display very low levels of cash flow, and high levels of leverage: their cash flow to assets ratio is $2.44 \%$, compared to 8.69\% for the other groups; their cash flow to tangible fixed assets ratio is $11.6 \%$

\footnotetext{
${ }^{16}$ Using time-invariant measures of ownership also allows to minimize the effects of measurement error in the ownership variables.
} 
compared to $43.45 \%$ for the rest of the sample ${ }^{17}$; and their total leverage to total assets ratio is $68.92 \%$, compared to $56.51 \%$ for the other groups ${ }^{18}$. Finally, SOEs display a very low level of labor productivity (measured as the ratio of sales to total number of employees): $66.85 \%$ compared to $139.66 \%$ for the rest of the sample.

As for foreign firms, they are large (employing 278.48 people), and very young (their average age being 6.35 years). Compared to the other ownership categories, they display the highest levels of labor productivity (165.76\%), and the lowest ratio of leverage to total assets (48.68\%).

Despite being typically the smallest of the four groups in terms of average number of employees (180.8), private firms exhibit the highest average assets growth and sales growth rates, respectively $10.74 \%$ and $13.06 \%$. They also exhibit the second highest cash flow to assets ratio (8.73\%). This figure is much higher compared to the corresponding figure reported by Carpenter and Petersen (2002) for US small listed firms (6.2\%).

It is interesting to note from Table 3 that the percentage of firm-years that export is highest for foreign firms (67.33\%) and lowest for SOEs (12.14\%) and collective firms (14.86\%). Furthermore, the foreign, private, and collective firms, all exhibit a cash flow to tangible fixed assets ratio in excess of $40 \%$. This figure is very high compared to corresponding figures registered for the US or Europe. For instance, Bond et al. (2003) report cash flow to capital ratios of $13.4 \%$ for the UK; $17.8 \%$ for Belgium; 11.9\%, for France; and 16\%, for Germany. Similarly, Cummins et al. (2006) report a ratio of $19 \%$ for US firms. The high cash flow to capital ratios displayed by Chinese non-state firms suggest that these firms have the ability to generate high profits. Also considering the high growth characterizing foreign and private firms, one could question whether these two factors are linked, i.e. whether it is actually the ability to generate high profits that makes it possible for Chinese firms to grow at such high rates.

\footnotetext{
${ }^{17}$ As cash flow is defined as net income plus depreciation, one could question whether these data could be biased due to firms' tendency to misreport profits. Liu and Xiao (2004) document that it is mainly private and collective firms, and not SOEs, which have the highest propensity to disguise profits. Hence, the rankings of the cash flow to asses ratios reported in Table 3 would not change taking this under-reporting into account. Considering that it is reasonable to assume that measurement error due to mis-reporting of profits is time-invariant, in our regressions, we account for it in the $v_{i}$ component of the error term of our estimating equations (see section 4.1).

${ }^{18}$ Leverage is defined as current plus non-current liabilities over total assets. This measure includes borrowing from banks as well as accounts payable, which represent short term financing provided by suppliers.
} 
In the sections that follow, we estimate firm-level assets growth equations augmented with cash flow, for our four categories of firms, to formally assess the extent to which the growth of firms in each of the categories is affected by the availability of internal finance.

\section{Empirical specifications and estimation methodology}

\subsection{Baseline model}

We initially estimate the following simple dynamic assets growth model augmented with cash flow ${ }^{19}$ :

(Assets growth $)_{i t}=a_{0}(\text { Assets growth })_{i(t-1)}+a_{1}(\text { Cash flow/total assets })_{i t}+v_{i}+v_{t}+e_{i t},(1)$

where the subscript $i$ identifies firms, and the subscript $t$, time. The error term in Equation (1) comprises three components: $v_{i}, v_{t}$, and $e_{i t} . v_{i}$ is a firm-specific component, encompassing all time-invariant firm characteristics likely to influence growth, as well as the time-invariant component of the measurement error affecting any of the regression variables. $v_{t}$ is a time-specific component accounting for possible business cycle effects, and $e_{i t}$, an idiosyncratic component. We control for $v_{i}$ by estimating our equation in first-differences and for $v_{t}$ by including time dummies in all our specifications. We estimate Equation (1) separately for the four ownership groups $^{20}$.

As discussed in Carpenter and Petersen (2002), in the presence of capital market imperfections, one should expect the coefficient $a_{1}$ to be slightly greater than one for those firms more likely to face financial constraints. This is because for these firms, external finance is typically more expensive than internal finance. Thus, should cash flow increase, financially constrained firms would be able to increase their assets

\footnotetext{
${ }^{19}$ This specification differs from that estimated by Carpenter and Petersen (2002) in two main respects. First, we estimate a dynamic model, while they estimate a static one. We chose a dynamic model, as the static model was clearly rejected by our specification tests. Second, as Carpenter and Petersen's (2002) sample is made up of listed US firm, they include Tobin's $Q$ as an additional regressor. As most of the firms in our sample are not listed, we were unable to construct Tobin's $Q$, and therefore exclude it from our regression. Later, we will show that our results are robust to controlling for investment opportunities in various alternative ways.

${ }^{20}$ All results were robust to including cash flow divided by beginning-of-period total assets instead of cash flow over contemporaneous total assets. Our results were also robust to including in our regression the lagged cash flow to assets ratio, in addition or in alternative to the contemporaneous cash flow to assets ratio.
} 
(which make up all possible uses of firms' cash flow) one-for-one ${ }^{21}$. Furthermore, as a higher cash flow also indicates a healthier balance sheet, firms that benefit from a higher cash flow are also likely to find it easier to obtain loans. Thus, in the presence of an increase in cash flow, firms more likely to face financing constraints will be able to increase their total assets slightly more than one-for-one, due to this leverage effect. On the other hand, financially healthy firms can always access external finance: changes in their internal finance should therefore only have a moderate effect or no effect at all on their growth.

Figure 1 illustrates this argument ${ }^{22}$. The horizontal axis measures cash flow $(C F)$ and the change in assets $(\triangle T A)$, and the vertical axis measures the cost of finance. $S$ denotes the supply of finance. The horizontal portion of this schedule reflects a situation in which internal finance $(C F)$ is used and priced at a constant shadow cost $R$. Once internal finance is exhausted, the firm must obtain loans, the cost of which increases the higher the loan asked for: this is reflected by the upward sloping portion of the $S$ curve $^{23}$. Once the firm has borrowed from banks up to a certain threshold, it will make use of alternative sources of finance. These include mainly accounts payable, but could also contain corporate bonds, commercial paper, loans from insurance and financial companies and other forms of market finance. For simplicity, we assume that these alternative sources of finance are more expensive than bank loans, and that their cost is constant (Petersen and Rajan, 1994) ${ }^{24}$. The threshold on bank borrowing can be determined either by credit rationing or by the cost of bank borrowing becoming prohibitive. Firms with unlimited access to bank credit should, in theory, never make use of the more expensive sources of finance. The IO schedule represents the firm's investment opportunities. If cash flow rises from $C F$ to $C F$ ', then the horizontal portion of the $S$ curve becomes longer, and, if the IO curve intersects the $S$ curve in its upward sloping portion, $\Delta A$ rises to $\Delta A^{\prime}$.

\footnotetext{
${ }^{21}$ In theory, it is also possible for firms to use part of their cash flow to pay off debts. In this case, the coefficient associated with cash flow could drop below one, even in the presence of liquidity constraints.

${ }^{22}$ This Figure is adapted from Carpenter and Petersen (2002).

${ }^{23}$ The more leveraged a firm is, the more incentives it will have to undertake more risky investment projects: this moral hazard situation explains why the supply of funds schedule is increasing once the firm has exhausted its internal funds (Hubbard, 1998).

${ }^{24}$ Contrary to Carpenter and Petersen (2002), our Figure 1 does not interpret the upper horizontal portion of the $S$ curve as equity issuance. This is because our sample consists mainly of unlisted firms, and to the fact that equity markets are still poorly developed in China. See Petersen and Rajan (1997) for a discussion of why it is reasonable to assume that accounts payable are more expensive than bank loans. As for market finance, it typically involves a higher degree of informational asymmetries between borrowers and lenders than bank lending, and can hence be considered as more expensive.
} 
Moreover, due to the increase in net worth from which the firm benefits, the upward portion of the $S$ curve becomes slightly flatter. This implies that, in the presence of financing constraints, a given increase in cash flow may be associated with a slightly more than one-for-one increase in total assets ${ }^{25}$. This precise quantitative prediction allows for a sharper test of the financing constraints hypothesis than could be achieved simply focusing on the links between investment and cash flow ${ }^{26}$.

It should be noted that Figure 1 is unlikely to apply to Chinese SOEs. As widely documented in the literature, these firms are in fact able to receive as many cheap loans from the state owned banks as they need, independent on profitability (Boyreau-Debray, 2003). This is a consequence of their need to respond to both social and political stresses, as well as to economic objectives (Bai et al., 2006). The supply of funds schedule is therefore likely to be horizontal for SOEs, and we do not expect their asset growth to be significantly affected by their cash flow ${ }^{27}$. On the other hand, we would expect a rise in cash flow to generate a more than one-for-one rise in total assets for the private and collective firms, which are typically discriminated against by the banking sector. As for foreign firms, the link between their cash flow and growth would depend on whether they make use of domestic credit markets or are financed by their parent company. In the former case, one could expect a more than one-to-one relationship, while in the latter, one would observe a cash flow coefficient either lower than one, or poorly determined altogether.

Equation (1) does not take into account investment opportunities, which are reflected in shifts in the $I O$ curve in Figure 1. This could induce bias in the cash flow coefficient, as cash flow could be accounting for the omitted investment opportunities (Cummins et al., 2006; Carpenter and Guariglia, 2008). Typically, investment opportunities are accounted for through Tobin's $Q$, which is defined as the market value of the firm over the replacement value of its total assets. Yet, because our

\footnotetext{
${ }^{25}$ This prediction relies on the assumption that the IO schedule is highly elastic compared to the supply of finance. This is a reasonable assumption considering that none of the firms in our sample is sufficiently large to be able to affect prices by growing.

${ }^{26}$ It has been argued that the links between investment and cash flow observed in the literature could be due to the latter variable proxying for investment opportunities, rather than to financing constraints (Cummins et al., 2006; Carpenter and Guariglia, 2008). If this were the case, however, a slightly higher than one-to-one relationship between investment and cash flow would not necessarily follow. Hence, finding such a relationship can be seen as reliable evidence for the presence of financing constraints.

${ }^{27}$ Note, however, that a positive association between investment and cash flow could still be observed for SOEs if managers wishing to pursue private objectives overinvested relative to the optimum, by using 'free cash flow' for unprofitable investment projects (Jensen, 1986; Carpenter, 1995). In our empirical analysis, we never observe such a positive association.
} 
sample is made up of unlisted firms, we are unable to calculate $Q$. We therefore account for investment opportunities in two alternative ways. First, we proxy them with the firm's future sales growth. Sales growth has been frequently used in the literature to proxy for demand factors (see for instance Konings et al., 2003, and Hutchinson and Xavier, 2006). Second, we include in our model time dummies interacted with industry dummies (in addition to the aggregate time dummies). This approach can be seen as an indirect way to account for investment opportunities, or more in general demand factors, as the dummies account for all time-varying demand shocks at the industry level (Brown et al., 2008). If a correlation of cash flow with investment opportunities were an important source of bias, then the cash flow coefficients should decline substantially when we include future sales growth or industry-level time dummies in our specification.

\subsection{Estimation methodology}

All equations are estimated in first-differences, to control for firm-specific, timeinvariant effects. Given possible endogeneity problems, we use a first-difference Generalized Method of Moments (GMM) approach (Arellano and Bond, 1991). Two or more lags of each of the regressors are used as instruments.

To check whether the first-difference GMM estimator is likely to suffer from finite sample bias, we compared the GMM and the Within Groups estimates of the coefficient on the lagged dependent variable in Equation (1). Because the Within Groups estimate is typically downward biased in short panels (Nickell, 1981), one would expect a consistent estimate of the coefficient on the lagged dependent variable to lie above this estimate. As our GMM coefficient was larger than its Within Groups counterpart, we concluded that the first-difference GMM estimates are unlikely to be subject to serious finite sample bias ${ }^{28}$.

To evaluate whether our instruments are legitimate and our model is correctly specified, we use two criteria: the Sargan test (also known as $J$ test) and the test for second-order serial correlation of the residuals in the differenced equation ( $\mathrm{m} 2)$. If the model is correctly specified, the variables in the instrument set should be uncorrelated

\footnotetext{
${ }^{28}$ If the estimates obtained using the first-difference GMM estimator lie close or below the Within Groups estimates, one could suspect the GMM estimate to be downward biased as well, possibly due to weak instruments. In such case, the use of a GMM system estimator (which combines in a system the original specification expressed in first differences and in levels) would be required (Blundell and Bond, 1998).
} 
with the error term in the relevant equation. The $J$ test is the Sargan test for overidentifying restrictions, which, under the null of instrument validity, is asymptotically distributed as a chi-square with degrees of freedom equal to the number of instruments less the number of parameters. The $m 2$ test is asymptotically distributed as a standard normal under the null of no second-order serial correlation of the differenced residuals, and provides a further check on the specification of the model and on the legitimacy of variables dated $t-2$ as instruments in the differenced equation ${ }^{29}$.

\section{Regression results}

\subsection{Baseline model}

Table 4 presents estimates of Equation (1). Column 1 refers to SOEs, and columns 2 to 4, respectively to foreign owned firms, private firms, and collective firms. Although small in magnitude, the coefficient associated with the lagged dependent variable is negative and precisely determined for all groups of firms. This can be seen as evidence for convergence. Except for the SOEs, the cash flow coefficient is positive, precisely determined, and higher than one, for all groups of firms. This indicates that the growth of these firms is restricted by their profit generating capacity, and that a higher cash flow leads to an improved net worth, making it easier for the firms to obtain additional loans. The cash flow coefficient is largest for privately owned (1.56) and collective firms (1.57), which also exhibit the largest cash flow to total assets ratios (respectively, 8.73\% and 9.38\%), and are less likely than state owned or foreign firms to access external finance ${ }^{30}$. The coefficient is much smaller (although still larger than one) for foreign owned firms (1.11), which may also be able to obtain financing from their parent company (Desai et al., 2004). As for SOEs, the insignificant cash flow coefficient that they exhibit reflects on the one hand, their very low level of cash flow to total assets (2.44\%), and on the other, the fact that these firms may still experience soft budget constraints. State owned banks typically lend to these firms, independently of their profitability, preventing them to go bankrupt, as

\footnotetext{
${ }^{29}$ If the un-differenced error terms are i.i.d., then the differenced residuals should display first-order, but not second-order serial correlation. Note that neither the $J$ test nor the $m 2$ test allow to discriminate between bad instruments and model specification.

${ }^{30}$ This finding confirms the conjecture made in Abrahams et al. (2007) that collective firms can in fact be considered as private firms.
} 
this would generate a significant social unrest (Bai et al., 2006; Boyreau-Debray, 2003). In terms of Figure 1, this suggests that SOEs indeed face a horizontal $S$ curve. Our results compare favorably with Héricourt and Poncet (2007) who, focusing on investment, also find that SOEs are the least financially constrained, while private firms are the most constrained. The Sargan test indicates some problems with the specification of the model and/or the validity of the instruments for private firms. Yet, because the $m 2$ test is satisfactory, we do not think this to be a serious issue.

Table 5 presents estimates of variants of Equation (1), which also control for investment opportunities. Columns 1, 3, 5, and 7 contain the estimates of the Equation where demand factors are accounted for with future sales growth ${ }^{31}$, while columns 2 , 4, 6, and 8 contain the estimates of the Equation which includes time dummies interacted with industry dummies. Surprisingly, from the odd columns, we can see that future sales growth always attracts a poorly determined coefficient. This suggests that sales growth may not be a good proxy for investment opportunities ${ }^{32}$. As for the coefficient on cash flow, we can see that it remains poorly determined for SOEs, while for the other groups of firms, it remains statistically significant and larger than one, both in the even and in the odd columns. The cash flow coefficients for all groups of firms become slightly lower when investment opportunities are accounted for with future sales growth. Yet, when we include time dummies interacted with industry dummies, they remain very similar to those reported in Table 4, suggesting that the correlation between cash flow and investment opportunities is unlikely to be a significant source of bias ${ }^{33}$.

These results confirm our initial conjecture that Chinese firms are very heterogeneous in terms of their degree of dependence on internal finance. Specifically, SOEs are the least dependent, while private and collective firms are the most dependent. As for foreign firms, their cash flow coefficients suggest that they also face some degree of internal finance dependence. This can be seen as evidence that these firms cannot only finance themselves through their parent company, but

\footnotetext{
${ }^{31}$ Sales growth is measured as the growth rate of real sales. Our results were robust to using the change in real sales as a fraction of total assets, as in Konings et al. (2003). Our results were also robust to including contemporaneous rather than future sales growth.

${ }^{32}$ For this reason, in all subsequent regressions, we will take into account investment opportunities including time dummies interacted with industry dummies.

${ }^{33}$ Between 2000 and 2005, we observe entry of new firms, and exit of existing firms from the sample. These decisions are potentially not random and could bias our results. All our findings were robust to only using a balanced panel in estimation. The results based on the balanced panel are not reported for brevity, but are available from the authors upon request.
} 
need to also rely on the profits that they generate internally, as well as on local financial markets. Their reliance on local financial markets can be inferred from their cash flow coefficients, which are larger than one, suggesting the presence of a leverage effect, whereby higher cash flow is associated with the possibility of obtaining more leverage.

Considering their very high growth rates and cash flow to assets ratios, it seems, however, that especially for private firms, the dependence on internal finance has been a source of stimulus rather than a constraint. It is likely that because these firms have very good investment opportunities ${ }^{34}$, and do not always have access to reasonably priced external finance, the higher and higher cash flows that they have been generating, have translated themselves into higher and higher growth rates. Whether there will be a limit to such growth will hence depend on whether these firms' competitive advantage will be eroded. If this happened, due for instance, to increasing labor costs, and/or to increased competition, then private firms' ability to generate profits may be reduced and cash flow could become a constraint rather than a stimulus to these firm's growth.

\subsection{Robustness tests}

\section{Excluding cash and equivalents from total assets}

Firms' total assets include the stock of cash and equivalents. It is possible that firms might absorb some of the short-run fluctuations in cash flow with cash and equivalents, leading to a positive relationship between changes in assets and cash flow, even in the absence of financing constraints (Carpenter and Petersen, 2002). To rule out this effect, we remove the "other current assets category” from our definition of growth and re-estimate our Equation (1) using this alternative definition of assets growth $^{35}$. We account for investment opportunities by including time dummies interacted with industry dummies. The results are presented in Table 6. The coefficient on cash flow declines substantially for all firms, except the collective ones. This is not surprising as the dependent variable no longer captures all potential uses of

\footnotetext{
${ }^{34}$ Evidence that Chinese firms face particularly good investment opportunities can be inferred from the fact that China is now one of the few low or low-middle income countries whose level of R\&D intensity has risen beyond 1\% (Hu and Jefferson, 2008).

${ }^{35}$ Our data do not allow us to separately identify cash and equivalents. These are included in the "other current assets category", which also includes prepaid expenses and advances, other current assets, deferred charges, and short term investments.
} 
internal finance. The fact that the coefficient is still precisely determined for foreign, private, and collective firms confirms that these firms face a certain degree of financial constraints.

\section{Alternative definition of ownership categories}

Table 7 presents results where firm ownership categories are defined on the basis of a $100 \%$ of paid-in-capital rule. According to this rule, a firm is defined as privately owned if private agents own $100 \%$ of its capital in each of the six years making up our sample. Foreign owned, state owned, and collectively owned categories are defined in a similar way. These new categories obviously contain fewer observations than the previous ones, as they do not include firms that changed their ownership status over the period considered. Time dummies interacted with industry dummies are included in all specifications to control for investment opportunities. The results are once again similar to those reported in Table 4: growth at SOEs is not affected by internal finance, growth at foreign owned firms is moderately affected, and growth at private and collective firms is most affected ${ }^{36}$.

\section{Extended model}

We next verify whether our results are robust to estimating a more general model, aimed at highlighting what might be other determinants of growth (see Becchetti and Trovato, 2002; Haeshmati, 2001; and Honjo and Harada, 2006, for a similar approach). In particular, we estimate the following equation:

(Assets growth $)_{i t}=a_{0}(\text { Assets growth })_{i(t-1)}+a_{1}(\text { Cash flow/total assets })_{i t}+$

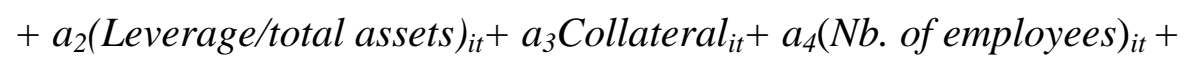

$+a_{5}(\text { Sales } / n b \text {. of employees })_{i t}+a_{6}$ Export $_{i t}+v_{i}+v_{t}+e_{i t}$

\footnotetext{
${ }^{36}$ Similar results were obtained when firms were classified as foreign owned, privately owned, state owned, or collectively owned on the basis of a $50 \%$ of paid-in-capital rule. We also tested whether the cash flow sensitivity of the growth of private firms with state or foreign participation below $10 \%$ differed from that of firms with state or foreign participation in excess of $10 \%$, but did not find statistically significant differences. We therefore concluded that even if part of their capital is paid in by the state or foreign agents, the growth of Chinese private enterprises remains positively affected by their profit generating capacity. These results are not reported for brevity, but available from the authors upon request.
} 
Our choice of regressors in Equation (2) is aimed at mirroring the regressors usually included in cross-country growth models. In particular, in addition to the cash flow to assets ratio, we include the total current and non-current liabilities to assets ratio, (Leverage/total assets). The effect of this variable is ambiguous: more leveraged firms could, on the one hand, grow faster having more resources. On the other hand, a higher leverage would make it more difficult for these firms to obtain further loans, making it harder to grow (Lang et al., 1996). This regressor is particularly interesting for linking our results with those obtained by macro studies on China's growth. For instance, using provincial data over the period 1989-2003, Guariglia and Poncet (2008) show that traditionally used indicators of financial development, as well as China specific measures of the distortions characterizing the financial system (such as the proportion of total loans provided by sate-owned commercial banks) are negatively related with growth. However, they find that this relationship has become less negative, and in some cases has even become positive after 2000, i.e. after major reforms of the banking system were undertaken in China (Podpiera, 2006; Allen et al., 2008b). By including, leverage in our growth equations, we aim at testing at the micro level the extent to which firms owned by different agents employ leverage as a means of expanding their size. If loans were systematically allocated inefficiently towards the worst performing firms, we could observe a negative relationship between leverage and growth ${ }^{37}$.

We also include the ratio of tangible fixed assets to total assets (Collateral). We expect the latter to exert a positive effect on growth, as firms able to post higher collateral find it easier to obtain loans necessary to fund their investment opportunities. Finally, we include three non-financial variables: the number of employees, which is a measure of size, aimed at testing whether small firms tend to grow faster; a measure of labor productivity (Sales / $n b$. of employees); and a dummy equal to 1 if firm $i$ exports at time $t$, and 0 otherwise (Export). We expect the latter two variables to positively affect growth ${ }^{38}$.

\footnotetext{
${ }^{37}$ Unfortunately, because our dataset does not contain data relative to informal finance, we were unable to include this information in our extended regression. This should not constitute a major source of bias: Ayyagari et al. (2008) document in fact that the use of informal sources of funds (defined as financing from informal sources such as a money lenders or informal banks) is relatively low in China (see Figure 2, p. 52, and Table 2, p. 57). Note that trade credit, which is often considered as a form of informal financing, is included within our Leverage variable.

${ }^{38}$ Authors like Evans (1987a, 1987b), who also focus on firm growth, show that growth also depends on firms' age. As age is missing for a number of observations in our sample, we did not include it in our preferred regression. The regression results including age, based on a smaller sample, showed that
} 
Table 8 presents the estimates of our extended model (Equation 2). Columns 1 to 4 refer respectively to SOEs, foreign owned firms, private firms, and collective firms. Once again, investment opportunities are accounted for by including industryspecific time dummies. As in the simple model, the coefficient on the lagged dependent variable is negative and precisely determined for all types of firms. A similar pattern as in Table 4 is observed for the cash flow coefficients, which are statistically significant and either exactly equal to one or slightly larger than one for private, collective, and foreign firms, and insignificant for SOEs. The coefficient is now largest for the private firms (1.35), while that of collective firms is now reduced to exactly 1.00, suggesting that once we control for other variables, the leverage effect disappears for these firms. Our main result that the growth of all firms, except the SOEs, is affected by internal finance is therefore robust to estimating an extended growth model.

As for the other financial variables, it is interesting to note that leverage plays a positive and significant effect on the growth of all types of firms ${ }^{39}$. This effect is slightly smaller for the foreign firms, compared to the private ones, the collectives, and the SOEs. Our findings suggest that SOEs finance their growth mainly through leverage, while private firms, which display the highest assets growth rate in the sample, make use of both their internal funds and leverage to finance their growth. Collateral has a positive and precisely determined effect both for private and collective firms, but not for SOEs and foreign firms, which can easily obtain loans respectively from the banking system and their parent company. The fact that collateral does not affect their growth confirms our priors that SOEs experience soft budget constraints, whereby they can obtain loans independently on their performance and financial conditions.

Although the banking system was characterized by a high degree of inefficiency in the first part of China's transition, given that it channelled funds mainly to inefficient SOEs, our findings suggest that this problem has become less severe in recent years, because SOEs have become fewer, and because the banking system is being gradually reformed. This conclusion is in line with Guariglia and Poncet (2008). It is likely that once China will have established a proper social

this variable was generally not precisely determined. The signs and significance of the other regressors were unchanged. These regressions are not reported for brevity, but are available from the authors upon request.

39 These results were robust to defining leverage net of accounts payable. 
security system, the "multitask" role of SOEs will come to an end. These firms will therefore either further decrease in number, or start operating on the basis of profit maximization, as the government, having no more incentives to keep them alive, will stop providing them with endless loans. The banking system will therefore be free to allocate financial resources to the most profitable firms.

Except for private firms, our measure of productivity generally does not affect growth appreciatively. The same holds for the firm's size measured in terms of the number of its employees: this variable only displays a positive and significant coefficient for private firms, indicating that in this group, larger firms are likely to exhibit faster assets growth. Surprisingly, being an exporter plays a negative and significant effect on the growth of private firms, but displays a poorly determined coefficient for other groups.

\section{Conclusions}

What is the final verdict on the effect of internal finance on the growth of Chinese firms? We have found that the growth of SOEs is not affected by the availability of cash flow, while that of foreign firms is moderately affected, and that of collective and private firms is most affected. These results are robust to accounting for investment opportunities in several ways, to considering assets growth net of cash, to defining our ownership categories in different ways, and to estimating an extended growth model. They suggest that SOEs are not subject to financing constraints, probably because of the important role they play in absorbing surplus labor and helping to maintain social stability, which guarantees them unlimited loans from the state banks. In contrast, foreign owned firms are financially constrained, although to a moderate degree, as they are also able to obtain funding from their parent company. Private and collective firms are the most financially constrained, being typically discriminated against by the banking sector. Yet, considering that over the period examined, private firms have achieved the highest growth rate among all ownership categories, as well as the second highest cash flow to assets ratio, we can conclude that for these firms, although clearly present, financial constraints were not binding: in fact, internal funds appear to have fostered rather than constrained private firms' growth.

Our paper complements Ayyagari et al. (2008) and Cull et al. (2007), who found that neither informal financing, nor trade credit played an important role in 
explaining the Chinese growth miracle, by suggesting that firms' ability to generate cash flow may have been an important factor instead. As private firms represent $62 \%$ of the firms in our sample, their ability to generate internal finance may therefore represent the solution to the puzzle of why, despite a malfunctioning financial system, the Chinese economy has grown at stellar rates in recent years.

Yet, if the competitive advantage of Chinese private firms were to be eroded, limiting their ability to generate high profits, financial constraints would quickly become increasingly binding for these firms, causing a significant reduction in economic growth. Thus, to make sure that the Chinese economy continues to thrive, measures will have to be taken ensuring a more widespread access to institutional finance.

\section{References}

Abraham, F., Konings, J., and V. Sloottmaekers (2007). "FDI spillovers in the Chinese manufacturing sector: evidence of firm heterogeneity.” CEPR Discussion Paper No. 6573.

Allen, F., Chakrabarti, R., De, S., Qian, J., and M. Qian (2008a). “The financial system capacities of China and India.” Mimeograph, Wharton Financial Institutions Center, University of Pennsylvania.

Allen, F., J. Qian, and M. Qian (2005). "Law, finance, and economic growth in China”, Journal of Financial Economics, 77, 57-116.

Allen, F., J. Qian, and M. Qian (2008b). “China’s financial system: past, present, and future”. In Brandt, L. and Rawski, T. (Eds): China's Great Economic Transformation, Cambridge, U.K.: Cambridge University Press.

Arellano, M. and S. Bond (1991). "Some tests of specification for panel data: Monte Carlo evidence and an application to employment equations.” Review of Economic Studies, 58, 277-97.

Ayyagari, M., Demirgüç-Kunt, A., and V. Maksimovic (2008). "Formal versus informal finance: evidence from China.” World Bank Policy Research Working Paper No. 4465.

Aziz, J., Duenwald, C. (2002). “Growth-financial intermediation nexus in China.” International Monetary Fund Discussion Paper No. 02/194.

Bai, C-E, Lu, J., and Z. Tao (2006). “The multitask theory of state enterprise reform: empirical evidence from China.” American Economic Review, 96, 353-57. 
Becchetti, L. and G. Trovato (2006). "The determinants of growth for small and medium sized firms. The role of the availability of external finance.” Small Business Economics, 19, 291-306.

Benito, A. (2005). "Financial pressure, monetary policy effects and inventories: firmlevel evidence from a market-based and a bank-based financial system.” Economica 72, 201-224.

Blundell, R. and S. Bond (1998). "Initial conditions and moment restrictions in dynamic panel data models.” Journal of Econometrics, 87, 115-43.

Bond, S., Elston, J., Mairesse, J., Mulkay, B. (2003). "Financial factors and investment in Belgium, France, Germany, and the United Kingdom: a comparison using company panel data.” Review of Economics and Statistics, 85, 153-65.

Bond, S. and J. Van Reenen (2007). Microeconometric models of investment and employment. In J. Heckman and E. Leamer (eds.), Handbook of Econometrics, Vol. 6, Edn 1, Chapter 65. North Holland: Elsevier, pp. 441798.

Boyreau-Debray, G. (2003). "Financial intermediation and growth: Chinese style.” World Bank Policy Research Working Paper No. 3027.

Brown, J., Fazzari, S., Petersen, B. (2008). "Financing innovation and growth: cash flow, external equity and the 1990s R\&D boom”. Journal of Finance (forthcoming).

Byrd, W. and Q. Lin (1990). China's Rural Industry, Structure, Development, and Reform. Oxford University Press.

Carpenter, R. (1995). “Finance constraints or free cash flow?” Empirica, 22, 185-209.

Carpenter, R. and A. Guariglia (2008). "Cash flow, investment, and investment opportunities: new tests using UK panel data” Journal of Banking and Finance, 32, 1894-1906.

Carpenter, R. and B. Petersen (2002). "Is the growth of small firms constrained by internal finance?” Review of Economics and Statistics, 84, 298-309.

Chen, H. (2006). "Development of financial intermediation and economic growth: the Chinese experience.” China Economic Review, 17, 347-362.

Cheng, X. and H. Degryse (2006). “The impact of bank and non-bank financial institutions on local economic growth in China.” LICOS Discussion Paper No. 171. 
Chow, C.K.W. and M.K.Y. Fung (1998). “Ownership structure, lending bias, and liquidity constraints: evidence from Shanghai's manufacturing sector.” Journal of Comparative Economics, 26, 300-16.

Chow, C.K.W., and M.K.Y. Fung (2000). "Small businesses and liquidity constraints in financing business investment: evidence from Shanghai's manufacturing sector.” Journal of Business Venturing, 15, 363-383.

Cleary, S. (1999). “The relationship between firm investment and financial status.” Journal of Finance, 54, pp. 673-92.

Cull, R., Xu, L. C., Zhu, T. (2007). “Formal finance and trade credit during China’s transition.” World Bank Working Paper No. WPS4204.

Cummins, J., K. Hasset, Oliner, S. (2006). "Investment behavior, observable expectations, and internal funds.” American Economic Review, 96, 796-810.

Desai, M., Foley, F., and J. Hines (2004). “A multinational perspective on capital structure choice and internal capital markets.” Journal of Finance, 59, 245187.

Dollar, D. and S-J Wei (2007). “Das (wasted) capital: firm ownership and investment efficiency in China.” NBER Working Paper No. 13103.

Evans, D. (1987a). “Tests of alternative theories of firm growth.” Journal of Political Economy, 95, 657-674.

Evans, D. (1987b). “The relationship between firm growth, size and age: estimates for 100 manufacturing industries.” Journal of Industrial Economics, 35, 567-581.

Guariglia, A. (2008). “Internal financial constraints, external financial constraints, and investment choice: evidence from a panel of UK firms.” Journal of Banking and Finance, 2008, 32, 1795-1809.

Guariglia, A. and S. Poncet (2008). "Could financial distortions be no impediment to economic growth after all? Evidence from China.” Journal of Comparative Economics, forthcoming.

Héricourt, J. and S. Poncet (2007). "FDI and credit constraints: firm level evidence in China”. CEPII Working Paper No. 2007-11. Economic Systems, forthcoming.

Heshmati, A. (2001). "On the growth of micro and small firms: evidence from Sweden.” Small Business Economics, 17, 213-28.

Ho, S., Bowles, P., and X. Dong (2003). "Letting go of the small: an analysis of the privatisation of rural enterprises in Jiangsu and Shandong.” Journal of Development Studies, 39, 1-26. 
Honjo, Y. and N. Harada (2006). "SME Policy, financial structure and firm growth: evidence from Japan.” Small Business Economics, 27, 289-300.

Hu, A. and G. Jefferson (2008). “Science and technology in China.” In L. Brandt and T. Rawski, eds., China's Great Economic Transformation, Cambridge, U.K.: Cambridge University Press.

Huang, Y. (2003). Selling China: foreign direct investment during the reform era. Cambridge University Press, New York.

Hubbard, G. (1998). “Capital market imperfections and investment”. Journal of Economic Literature, 35, 193-225.

Hutchinson, J. and A. Xavier (2006). “Comparing the impact of credit constraints on the growth of SMEs in a transition country with an established market economy.” Small Business Economics, 27, 169-79.

Jefferson, G. and S. Jian (2006). "Privatization and restructuring in China: evidence from shareholding ownership, 1995-2001.” Journal of Comparative Economics, 34, 146-66.

Jensen, M. (1996). “Agency costs of free cash flow, corporate finance, and takeovers.” American Economic Review, 76, 323-29.

Kaplan, S. and Zingales, L. (1997). "Do investment-cash flow sensitivities provide useful measures of financing constraints?” Quarterly Journal of Economics, 112, 169-215.

Konings. J., Rizov, M., and H. Vandenbussche (2003). "Investment and financial constraints in transition economies: micro evidence from Poland, the Czech Republic, Bulgaria, and Romania.” Economics Letters, 78, 253-58.

Lang, L., Ofek, E., and R. M. Stulz (1996). "Leverage, investment, and firm growth.” Journal of Financial Economics, 40, 3-29.

Levine, R. (2005). "Finance and growth: theory and evidence”, Chapter 12 in Aghion, P. and Durlauf, S. (Eds): Handbook of Economic Growth, The Netherlands: Elsevier Science.

Liu, T. and K-W Li (2001). “Impact of financial resources liberalization in China’s economic growth: provincial evidence.” Journal of Asian Economics, 12, 245262.

Liu, Q. and G. Xiao (2004). "Look who are disguising profits: an application to Chinese industrial firms.” Mimeograph, University of Hong Kong. 
Nickell, S. (1981). "Biases in dynamic models with fixed effects.” Econometrica, 49, 1417-26

Petersen, M. and R. Rajan (1997). “Trade credit: theories and evidence.” Review of Financial Studies, 10, 661-691.

Petersen, M. and R. Rajan (1994). "The benefits of lending relationships: evidence from small business data.” Journal of Finance, 49, 3-37.

Podpiera, R. (2006). "Progress in China's banking sector reform: has banking behavior changed?” IMF Working Paper No. 06/71.

Qin, D. and H. Song (2008). "Sources of investment inefficiency: the case of fixedasset investment in China.” Journal of Development Economics (forthcoming).

Schiantarelli, F. 1995. "Financial constraints and investment: methodological issues and international evidence.” Oxford Review of Economic Policy 12, 70-89.

Song L. (1990). “Convergence: a comparison between China’s state enterprises and rural government-owned enterprises.” In: W. Byrd and Q. Lin, China’s Rural Industry, Structure, Development, and Reform, Oxford University Press.

Wei, Z, Xie, F., and S. Zhang (2005). “Ownership structure and firm value in China’s privatized firms.” Journal of Financial and Quantitative Analysis, 40, 87-108.

World Bank (2003). “Improving investment climate in China.” Mimeograph, Washington DC: The World Bank. 


\section{Appendix: Data}

$\underline{\text { Structure of the unbalanced panel }}$

\begin{tabular}{|c|c|c|c|}
\hline $\begin{array}{l}\text { Number of obs. } \\
\text { per firm }\end{array}$ & $\begin{array}{c}\text { Number of } \\
\text { observations }\end{array}$ & Percent & Cumulative \\
\hline 1 & 129,608 & 12.25 & 12.25 \\
\hline 2 & 234,072 & 22.12 & 34.37 \\
\hline 3 & 160,593 & 15.18 & 49.55 \\
\hline 4 & 155,784 & 14.72 & 64.28 \\
\hline 5 & 149,540 & 14.13 & 78.41 \\
\hline 6 & 228,402 & 21.59 & 100.00 \\
\hline Total & $1,057,999$ & 100.00 & \\
\hline Year & $\begin{array}{c}\text { Number of } \\
\text { observations }\end{array}$ & Percent & Cumulative \\
\hline 2000 & 130,306 & 12.32 & 12.32 \\
\hline 2001 & 139,596 & 13.19 & 25.51 \\
\hline 2002 & 151,013 & 14.27 & 39.78 \\
\hline 2003 & 166,402 & 15.73 & 55.51 \\
\hline 2004 & 236,955 & 22.40 & 77.91 \\
\hline 2005 & 233,727 & 22.09 & 100.00 \\
\hline Total & $1,057,999$ & 100.00 & \\
\hline
\end{tabular}

\section{Definitions of the variables used}

Total assets: sum of the firm's fixed and current assets, where fixed assets include tangible fixed assets, intangible fixed assets, and other fixed assets; and current assets include inventories, accounts receivable, and other current assets.

Other current assets: sum of cash and equivalents, prepaid expenses and advances, other current assets, deferred charges, and short term investments.

Cash flow: net income plus depreciation.

Leverage: ratio of current liabilities plus non-current liabilities to total assets, where current liabilities include bank loans, accounts payable, and other current liabilities; and non-current liabilities include long-term debt and other non-current liabilities.

Collateral: ratio of tangible assets to total assets.

Sales: firm’s total sales (including domestic and overseas sales).

Employees: total number of people employed by the firm.

Export: dummy variable equal to 1 if the firm exports a positive amount.

Deflators: all variables are deflated using provincial GDP deflators, taken from various issues of the China Statistical Yearbook. 
Figure 1: Financing hierarchy and investment opportunities

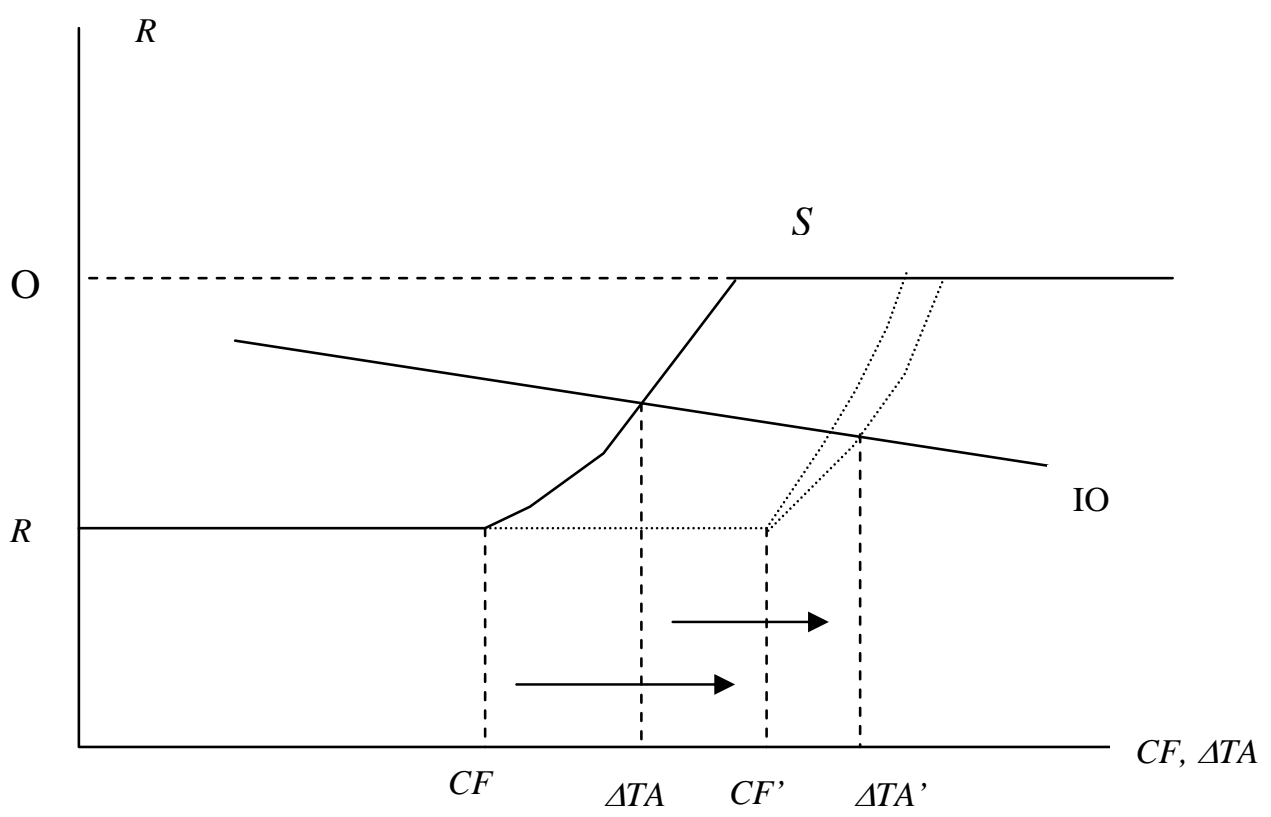

Note: $C F=$ cash flow; $\Delta T A=$ change in total assets; $R=$ constant shadow cost of internal finance; $I O=$ investment opportunities schedule; $O=$ cost of borrowing from other sources.

Source: Adapted from Carpenter and Petersen (2002). 
Table 1: Distribution of observations by ownership type

\begin{tabular}{l|llll}
\hline & $\begin{array}{l}\text { State- } \\
\text { owned }\end{array}$ & Foreign & Private & Collective \\
& $(1)$ & $(2)$ & $(3)$ & $(4)$ \\
& & & & \\
2000 & 21.37 & 12.22 & 41.48 & 24.10 \\
2001 & 16.15 & 13.40 & 49.50 & 19.24 \\
2002 & 13.00 & 13.35 & 56.47 & 15.55 \\
2004 & 9.03 & 14.32 & 63.73 & 11.31 \\
2005 & 5.67 & 15.23 & 70.12 & 7.66 \\
All & 4.34 & 15.38 & 73.53 & 6.33 \\
& & & & \\
\hline
\end{tabular}

Note: All numbers in this Table are percentages.

Table 2: Asset composition by ownership type

\begin{tabular}{l|llll}
\hline & $\begin{array}{l}\text { State- } \\
\text { owned }\end{array}$ & Foreign & Private & Collective \\
& $(1)$ & $(2)$ & $(3)$ & $(4)$ \\
& & & & \\
& & & & \\
Tangibles & 42.44 & 33.43 & 35.67 & 34.42 \\
Intangibles & 2.09 & 2.11 & 2.08 & 1.13 \\
Other fixed assets & 5.93 & 3.90 & 4.35 & 4.51 \\
Accounts receivable & 12.60 & 19.19 & 19.20 & 19.44 \\
Inventories & 17.14 & 20.71 & 18.86 & 19.35 \\
Other current assets & 19.81 & 20.66 & 19.83 & 21.15 \\
& & & & \\
\hline
\end{tabular}

Note: All numbers in this Table are percentages. 
Table 3: Sample means

\begin{tabular}{|c|c|c|c|c|}
\hline & 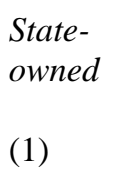 & $\begin{array}{l}\text { Foreign } \\
\text { (2) }\end{array}$ & $\begin{array}{l}\text { Private } \\
\text { (3) }\end{array}$ & $\begin{array}{l}\text { Collective } \\
\text { (4) }\end{array}$ \\
\hline Assets growth & 0.60 & 7.02 & 10.74 & 4.16 \\
\hline Sales growth & 0.84 & 10.98 & 13.06 & 4.55 \\
\hline Employment growth & -8.09 & 5.65 & 2.84 & -2.45 \\
\hline Assets & 390.50 & 351.41 & 176.99 & 158.72 \\
\hline Sales & 213.24 & 365.04 & 197.11 & 187.49 \\
\hline Nb. of employees & 347.42 & 278.48 & 180.83 & 209.15 \\
\hline Age & 24.71 & 6.35 & 7.05 & 14.35 \\
\hline Cash flow/total assets & 2.44 & 7.98 & 8.73 & 9.38 \\
\hline Cash flow/tangible fixed assets & 11.63 & 47.12 & 41.83 & 47.44 \\
\hline Leverage / total assets & 68.92 & 48.68 & 57.70 & 60.11 \\
\hline Tangible fixed assets/total assets & 42.44 & 33.43 & 35.67 & 34.42 \\
\hline Sales/nb. of employees & 66.85 & 165.76 & 137.19 & 119.69 \\
\hline Export & 12.14 & 67.33 & 22.40 & 14.86 \\
\hline Observations & 104,520 & 154,395 & 650,475 & 121,705 \\
\hline
\end{tabular}

Notes: Assets and sales are expressed in thousands of yuan. All other variables except age and number of employees are expressed in percentage terms. Export is a dummy variable equal to 1 if the firm exports, and 0 otherwise. All variables were deflated using provincial GDP deflators. See the Appendix for complete definitions of all variables. 
Table 4: Simple assets growth model

\begin{tabular}{|c|c|c|c|c|}
\hline & 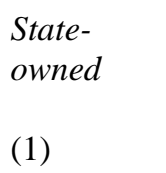 & $\begin{array}{l}\text { Foreign } \\
\text { (2) }\end{array}$ & $\begin{array}{l}\text { Private } \\
\text { (3) }\end{array}$ & $\begin{array}{l}\text { Collective } \\
\text { (4) }\end{array}$ \\
\hline Assets growth $_{i(t-1)}$ & $\begin{array}{l}-0.052^{* * *} \\
(0.010)\end{array}$ & $\begin{array}{l}-0.090^{* * *} \\
(0.009)\end{array}$ & $\begin{array}{l}-0.066^{* * *} \\
(0.005)\end{array}$ & $\begin{array}{l}-0.118^{* * *} \\
(0.01)\end{array}$ \\
\hline $\begin{array}{l}\text { (Cash flow / } \\
\text { total assets) }{ }_{\text {it }}\end{array}$ & $\begin{array}{l}0.375 \\
(0.29)\end{array}$ & $\begin{array}{l}1.114^{* * * *} \\
(0.13)\end{array}$ & $\begin{array}{l}1.557^{* * * *} \\
(0.18)\end{array}$ & $\begin{array}{l}1.567 * * * \\
(0.44)\end{array}$ \\
\hline $\begin{array}{l}J(p \text {-value }) \\
m 2\end{array}$ & $\begin{array}{l}0.06 \\
0.07\end{array}$ & $\begin{array}{l}0.05 \\
-0.54\end{array}$ & $\begin{array}{l}0.00 \\
0.63\end{array}$ & $\begin{array}{l}0.03 \\
1.11\end{array}$ \\
\hline Observations & 47,067 & 55,400 & 159,967 & 47,759 \\
\hline
\end{tabular}

Notes: All specifications were estimated using a GMM first-difference specification. The figures reported in parentheses are asymptotic standard errors. Time dummies were included in all specifications. Standard errors and test statistics are asymptotically robust to heteroskedasticity. Instruments in all columns are (Assets growth) $)_{i(t-2) \text {, }}$

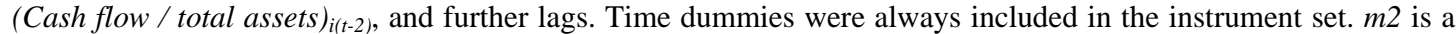
test for second-order serial correlation in the first-differenced residuals, asymptotically distributed as $\mathrm{N}(0,1)$ under the null of no serial correlation. The $J$ statistic is a test of the overidentifying restrictions, distributed as chi-square under the null of instrument validity. Also see Notes to Table $3 . *$ indicates significance at the $10 \%$ level. ** indicates significance at the $5 \%$ level. $* * *$ indicates significance at the $1 \%$ level. 
Table 5: Simple assets growth model controlling for investment opportunities

\begin{tabular}{|c|c|c|c|c|c|c|c|c|}
\hline & $\begin{array}{l}\text { State- } \\
\text { owned } \\
\text { (1) }\end{array}$ & $\begin{array}{l}\text { State- } \\
\text { owned } \\
\text { (2) }\end{array}$ & $\begin{array}{l}\text { Foreign } \\
\text { (3) }\end{array}$ & $\begin{array}{l}\text { Foreign } \\
\text { (4) }\end{array}$ & $\begin{array}{l}\text { Private } \\
\text { (5) }\end{array}$ & $\begin{array}{l}\text { Private } \\
\text { (6) }\end{array}$ & $\begin{array}{l}\text { Collective } \\
\text { (7) }\end{array}$ & $\begin{array}{l}\text { Collective } \\
\text { (8) }\end{array}$ \\
\hline $\begin{array}{l}\text { Assets } \\
\text { growth }_{i(t-1)}\end{array}$ & $\begin{array}{l}-0.041^{* * *} \\
(0.014)\end{array}$ & $\begin{array}{l}-0.053^{* * *} \\
(0.010)\end{array}$ & $\begin{array}{l}-0.075^{* * *} \\
(0.01)\end{array}$ & $\begin{array}{l}-0.090^{* * *} \\
(0.009)\end{array}$ & $\begin{array}{l}-0.051^{* * *} \\
(0.007)\end{array}$ & $\begin{array}{l}-0.066^{* * *} \\
(0.005)\end{array}$ & $\begin{array}{l}-0.107^{* * *} \\
(0.01)\end{array}$ & $\begin{array}{l}-0.112 * * * \\
(0.01)\end{array}$ \\
\hline $\begin{array}{l}\text { (Cash flow / } \\
\text { total assets) }\end{array}$ & $\begin{array}{l}0.022 \\
(0.38)\end{array}$ & $\begin{array}{l}0.331 \\
(0.29)\end{array}$ & $\begin{array}{l}0.911 * * * \\
(0.26)\end{array}$ & $\begin{array}{l}1.115^{* * * *} \\
(0.18)\end{array}$ & $\begin{array}{l}1.415^{* * *} \\
(0.23)\end{array}$ & $\begin{array}{l}1.575^{* * * *} \\
(0.18)\end{array}$ & $\begin{array}{l}1.103^{* * *} \\
(0.17)\end{array}$ & $\begin{array}{l}1.590^{* * * *} \\
(0.40)\end{array}$ \\
\hline $\begin{array}{l}\text { Sales } \\
\text { growth }_{i(t+1)}\end{array}$ & $\begin{array}{l}-0.120 \\
(0.10)\end{array}$ & & $\begin{array}{l}-0.281 \\
(0.41)\end{array}$ & & $\begin{array}{l}0.115 \\
(0.09)\end{array}$ & & $\begin{array}{l}-0.148 \\
(0.17)\end{array}$ & \\
\hline $\begin{array}{l}\text { Time dummies } \\
\text { interacted with } \\
\text { ind. dummies }\end{array}$ & No & Yes & No & Yes & No & Yes & No & Yes \\
\hline $\begin{array}{l}J(p \text {-value }) \\
m 2\end{array}$ & $\begin{array}{l}0.04 \\
-0.56\end{array}$ & $\begin{array}{l}0.05 \\
-0.06\end{array}$ & $\begin{array}{l}0.002 \\
-1.71\end{array}$ & $\begin{array}{l}0.06 \\
-0.57\end{array}$ & $\begin{array}{l}0.00 \\
1.82\end{array}$ & $\begin{array}{l}0.00 \\
1.24\end{array}$ & $\begin{array}{l}0.01 \\
0.25\end{array}$ & $\begin{array}{l}0.03 \\
1.18\end{array}$ \\
\hline Observations & 29,652 & 47,067 & 35,875 & 55,400 & 95,343 & 159,967 & 29,881 & 47,759 \\
\hline
\end{tabular}

Notes: All specifications were estimated using a GMM first-difference specification. The figures reported in parentheses are asymptotic standard errors. Time dummies were included in all specifications. In columns 2, 4, 6, and 8, time dummies interacted with industry dummies were also included. Standard errors and test statistics are asymptotically robust to heteroskedasticity. Instruments in all columns are (Assets growth) ${ }_{i(t-2)}$, (Cash flow / total

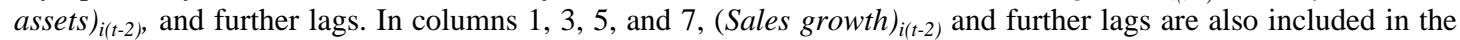
instrument set. Time dummies were always included in the instrument set. In columns 2, 4, 6, and 8, time dummies interacted with industry dummies were also included in the instrument set. $m 2$ is a test for second-order serial correlation in the first-differenced residuals, asymptotically distributed as $\mathrm{N}(0,1)$ under the null of no serial correlation. The $J$ statistic is a test of the overidentifying restrictions, distributed as chi-square under the null of instrument validity. Also see Notes to Table $3 . *$ indicates significance at the $10 \%$ level. ** indicates significance at the $5 \%$ level. ${ }^{* * *}$ indicates significance at the $1 \%$ level. 
Table 6: Simple assets growth model augmented with industry-specific time dummies: firm assets growth measured net of other current assets

\begin{tabular}{|c|c|c|c|c|}
\hline & 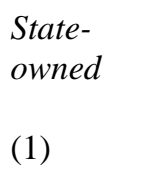 & $\begin{array}{l}\text { Foreign } \\
\text { (2) }\end{array}$ & $\begin{array}{l}\text { Private } \\
\text { (3) }\end{array}$ & $\begin{array}{l}\text { Collective } \\
\text { (4) }\end{array}$ \\
\hline Assets growth $_{i(t-1)}$ & $\begin{array}{l}-0.101^{* * *} \\
(0.01)\end{array}$ & $\begin{array}{l}-0.113^{* * *} \\
(0.009)\end{array}$ & $\begin{array}{l}-0.099 * * * \\
(0.005)\end{array}$ & $\begin{array}{l}-0.132^{* * *} \\
(0.01)\end{array}$ \\
\hline $\begin{array}{l}\text { (Cash flow / } \\
\text { total assets) it }\end{array}$ & $\begin{array}{l}0.725 \\
(0.40)\end{array}$ & $\begin{array}{l}0.635^{* * * *} \\
(0.14)\end{array}$ & $\begin{array}{l}0.797 * * * \\
(0.20)\end{array}$ & $\begin{array}{l}1.650^{* * * *} \\
(0.50)\end{array}$ \\
\hline $\begin{array}{l}J \text { (p-value }) \\
m 2\end{array}$ & $\begin{array}{l}0.60 \\
-0.37\end{array}$ & $\begin{array}{l}0.48 \\
0.18\end{array}$ & $\begin{array}{l}0.00 \\
0.63\end{array}$ & $\begin{array}{l}0.15 \\
-0.85\end{array}$ \\
\hline Observations & 23,225 & 36,936 & 109,634 & 25,781 \\
\hline
\end{tabular}

Notes: All specifications were estimated using a GMM first-difference specification. The figures reported in parentheses are asymptotic standard errors. Time dummies and time dummies interacted with industry dummies were included in all specifications. Standard errors and test statistics are asymptotically robust to

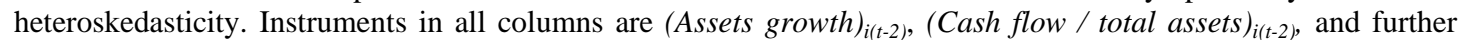
lags. Time dummies and time dummies interacted with industry dummies were always included in the instrument set. $m 2$ is a test for second-order serial correlation in the first-differenced residuals, asymptotically distributed as $\mathrm{N}(0,1)$ under the null of no serial correlation. The $J$ statistic is a test of the overidentifying restrictions, distributed as chi-square under the null of instrument validity. Also see Notes to Table 3. * indicates significance at the $10 \%$ level. ** indicates significance at the $5 \%$ level. *** indicates significance at the $1 \%$ level. 
Table 7: Simple assets growth model augmented with industry-specific time dummies: alternative ownership definition (based on a $100 \%$ paid-in capital rule)

\begin{tabular}{|c|c|c|c|c|}
\hline & $\begin{array}{l}\text { State- } \\
\text { owned } \\
\text { (1) }\end{array}$ & $\begin{array}{l}\text { Foreign } \\
\text { (2) }\end{array}$ & $\begin{array}{l}\text { Private } \\
\text { (3) }\end{array}$ & $\begin{array}{l}\text { Collective } \\
\text { (4) }\end{array}$ \\
\hline Assets growth ${ }_{i(t-1)}$ & $\begin{array}{l}-0.055^{* * *} \\
(0.01)\end{array}$ & $\begin{array}{l}-0.088^{* * *} \\
(0.01)\end{array}$ & $\begin{array}{l}-0.065 \text { *** } \\
(0.007)\end{array}$ & $\begin{array}{l}-0.107^{* * *} \\
(0.02)\end{array}$ \\
\hline $\begin{array}{l}\text { (Cash flow / } \\
\text { total assets) }\end{array}$ & $\begin{array}{l}0.228 \\
(0.45)\end{array}$ & $\begin{array}{l}1.084^{* * *} \\
(0.17)\end{array}$ & $\begin{array}{l}1.173^{* * *} \\
(0.23)\end{array}$ & $\begin{array}{l}1.413^{* * *} \\
(0.61)\end{array}$ \\
\hline $\begin{array}{l}J \text { (p-value) } \\
m 2\end{array}$ & $\begin{array}{l}0.93 \\
-0.05\end{array}$ & $\begin{array}{l}0.77 \\
0.18\end{array}$ & $\begin{array}{l}0.00 \\
1.09\end{array}$ & $\begin{array}{l}0.09 \\
-1.98\end{array}$ \\
\hline Observations & 26,735 & 28,785 & 83,697 & 17,203 \\
\hline
\end{tabular}

Notes: All specifications were estimated using a GMM first-difference specification. The figures reported in parentheses are asymptotic standard errors. Time dummies and time dummies interacted with industry dummies were included in all specifications. Standard errors and test statistics are asymptotically robust to

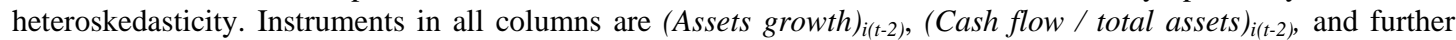
lags. Time dummies and time dummies interacted with industry dummies were always included in the instrument set. $m 2$ is a test for second-order serial correlation in the first-differenced residuals, asymptotically distributed as $\mathrm{N}(0,1)$ under the null of no serial correlation. The $J$ statistic is a test of the overidentifying restrictions, distributed as chi-square under the null of instrument validity. Also see Notes to Table $3 . *$ indicates significance at the $10 \%$ level. ** indicates significance at the $5 \%$ level. *** indicates significance at the $1 \%$ level. 
Table 8: Extended assets growth model

\begin{tabular}{|c|c|c|c|c|}
\hline & 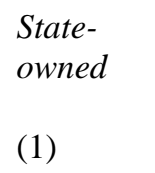 & $\begin{array}{l}\text { Foreign } \\
\text { (2) }\end{array}$ & $\begin{array}{l}\text { Private } \\
\text { (3) }\end{array}$ & $\begin{array}{l}\text { Collective } \\
\text { (4) }\end{array}$ \\
\hline Assets growth ${ }_{i(t-1)}$ & $\begin{array}{l}-0.056^{* * *} \\
(0.01)\end{array}$ & $\begin{array}{l}-0.095 * * * \\
(0.01)\end{array}$ & $\begin{array}{l}-0.060^{* * *} \\
(0.006)\end{array}$ & $\begin{array}{l}-0.122^{* *} \\
(0.01)\end{array}$ \\
\hline $\begin{array}{l}\text { (Cash flow / }_{\text {total assets })_{\text {it }}}\end{array}$ & $\begin{array}{l}-0.212 \\
(0.31)\end{array}$ & $\begin{array}{l}1.119 * * * \\
(0.16)\end{array}$ & $\begin{array}{l}1.353^{* * *} \\
(0.18)\end{array}$ & $\begin{array}{l}1.000^{* * *} \\
(0.36)\end{array}$ \\
\hline $\begin{array}{l}\text { (Leverage / } \\
\text { total assets) it }\end{array}$ & $\begin{array}{l}0.392^{* * *} \\
(0.08)\end{array}$ & $\begin{array}{l}0.147^{*} \\
(0.10)\end{array}$ & $\begin{array}{l}0.305^{* * * *} \\
(0.06)\end{array}$ & $\begin{array}{l}0.404^{* * * *} \\
(0.10)\end{array}$ \\
\hline Collateral $_{\text {it }}$ & $\begin{array}{l}0.153 \\
(0.11)\end{array}$ & $\begin{array}{l}0.147 \\
(0.18)\end{array}$ & $\begin{array}{l}0.271^{* * * *} \\
(0.06)\end{array}$ & $\begin{array}{l}0.580 * * * \\
(0.15)\end{array}$ \\
\hline Nb. of employees it & $\begin{array}{l}-0.005 \\
(0.005)\end{array}$ & $\begin{array}{l}-0.020 \\
(0.03)\end{array}$ & $\begin{array}{l}0.018^{* *} \\
(0.008)\end{array}$ & $\begin{array}{l}-0.007 \\
(0.01)\end{array}$ \\
\hline $\begin{array}{l}\text { (Sales / } \\
\text { nb. of employees) }\end{array}$ & $\begin{array}{l}-0.029 \\
(0.05)\end{array}$ & $\begin{array}{l}-0.037 \\
(0.04)\end{array}$ & $\begin{array}{l}0.148^{* * *} \\
(0.04)\end{array}$ & $\begin{array}{l}0.014 \\
(0.07)\end{array}$ \\
\hline Export $_{i t}$ & $\begin{array}{l}6.519 \\
(4.91)\end{array}$ & $\begin{array}{l}-5.546 \\
(4.86)\end{array}$ & $\begin{array}{l}-8.027^{* *} \\
(3.28)\end{array}$ & $\begin{array}{l}1.830 \\
(5.09)\end{array}$ \\
\hline $\begin{array}{l}J \text { (p-value }) \\
m 2\end{array}$ & $\begin{array}{l}0.070 \\
-0.61\end{array}$ & $\begin{array}{l}0.001 \\
-0.84\end{array}$ & $\begin{array}{l}0.00 \\
1.77\end{array}$ & $\begin{array}{l}0.002 \\
1.59\end{array}$ \\
\hline Observations & 47,067 & 55,400 & 159,967 & 47,759 \\
\hline
\end{tabular}

Notes: All specifications were estimated using a GMM first-difference specification. The figures reported in parentheses are asymptotic standard errors. Time dummies and time dummies interacted with industry dummies were included in all specifications. Standard errors and test statistics are asymptotically robust to

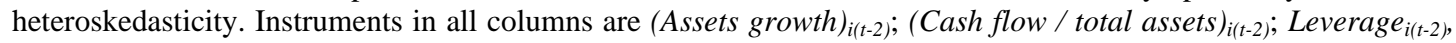
Collateral $_{i(t-2)}$; $(\mathrm{Nb} \text {. of employees) })_{i(t-2)}$; (Sales / nb of employees) $)_{i(t-2)}$; Export $_{i(t-2)}$; and further lags. Time dummies and time dummies interacted with industry dummies were always included in the instrument set. $m 2$ is a test for second-order serial correlation in the first-differenced residuals, asymptotically distributed as $\mathrm{N}(0,1)$ under the null of no serial correlation. The $J$ statistic is a test of the overidentifying restrictions, distributed as chi-square under the null of instrument validity. Also see Notes to Table 3. * indicates significance at the $10 \%$ level. ** indicates significance at the $5 \%$ level. $* * *$ indicates significance at the $1 \%$ level. 